\title{
STUDI LITERATUR: PENINGKATAN ORAL ACTIVITYDAN HASIL BELAJAR KOGNITIF MELALUI PENERAPAN MODEL PEMBELAJARAN SEARCH, SOLVE, CREATE AND SHARE (SSCS) MATERI SISTEM EKSKRESI PADA MANUSIA
}

\author{
Fasaila Nadif Widyati ${ }^{1}$, Hani Irawati, M.Pd ${ }^{2}$ \\ ${ }^{1,2}$ Pendidikan Biologi, FKIP, Universitas Ahmad Dahlan, Yogyakarta, 55166, Indonesia \\ Email: ${ }^{1}$ fasailanadifwi29@gmail.com, ${ }^{2}$ hani@pbio.uad.ac.id
}

Diajukan: 28 Juli 2020; Diterima: 29 September 2020; Diterbitkan: 31 Oktober 2020

\begin{abstract}
Abstrak: Dominansi pendekatan pembelajaran teacher center menyebabkan oral activity siswa dan hasil belajar kognitif siswa rendah pada materi sistem ekskresi. Penerapan model pembelajaran SSCS diharapkan dapat meningkatkan oral activity dan hasil belajar kognitif siswa. Penelitian ini bertujuan untuk mengetahui peningkatan oral activity dan hasil belajar kognitif siswa melalui model pembelajaran SSCS pada materi sistem ekskresi berdasarkan studi literatur. Jenis penelitian ini merupakan penelitian studi literatur. Artikel ilmiah sebagai data penelitian berasal dari jurnal nasional, prosiding dan repository. Validasi artikel dilakukan dengan pertimbangan artikel ilmiah bersifat open access, kualitas metodologi penelitian, kualitas penyajian data dan pembahasan, kecukupan data yang relevan, referensi mutakhir. Teknik pengumpulan data dengan cara koding definisi dan format penyajian data dalam tabel. Teknik analisis data menggunakan analisis deskriptif. Berdasarkan studi literatur menunjukkan bahwa model pembelajaran SSCS dapat meningkatkan oral activity dan hasil belajar kognitif siswa. Hal ini diketahui melalui analisis data artikel ilmiah relevan terdapat pengaruh yang signifikan terhadap peningkatan oral activity dan hasil belajar kognitif. Oral activity siswa terlihat dalam penerapan model pembelajaran SSCS pada tahapan solve dan share. Model pembelajaran SSCS mendukung siswa mengembangkan kemampuan berpikir sehingga perolehan hasil belajar kognitif siswa meningkat. Selain itu, model pembelajaran SSCS dapat diterapkan pada materi sistem ekskresi.
\end{abstract}

Kata Kunci: oral activity, hasil belajar kognitif, model pembelajaran Search, Solve, Create and Share (SSCS), studi literatur

\begin{abstract}
The dominance of the teacher center learning approach causes students' oral activity and students' cognitive learning outcomes to be low on the excretory system material. The application of the SSCS learning model is expected to improve students' oral activity and cognitive learning outcomes. This study aims to determine the increase in oral activity and student cognitive learning outcomes through the SSCS learning model on excretory system material based on literature studies. This type of research is a literature study research. Scientific articles as research data come from national journals, proceedings and repositories. Article validation is carried out with consideration of open access scientific articles, quality of research methodology, quality of data presentation and discussion, adequacy of relevant data, up-to-date references. Data collection techniques by coding the definition and format of data presentation in tables. The data analysis technique used descriptive analysis. Based on the literature study, it shows that the SSCS learning model can improve students' oral activity and cognitive learning outcomes. It is known that through data analysis of relevant scientific articles there is a significant effect on increasing oral activity and cognitive learning outcomes. The students' oral activity can be seen in the application of the SSCS learning model at the solve and share stages. The SSCS learning model supports students to develop thinking skills so that the acquisition of students' cognitive learning outcomes increases. In addition, the SSCS learning model can be applied to the excretory system material.
\end{abstract}

Keywords: oral activity, cognitive learning outcomes, learning model Search, Solve, Create and Share (SSCS), literature study

\section{Pendahuluan}

Pembelajaran merupakan proses kegiatan belajar mengajar yang melibatkan interaksi antara siswa dan guru. Siswa bertindak sebagai subjek pembelajaran, sedangkan guru bertindak sebagai fasilitator yang mendampingi siswa untuk mencapai tujuan pembelajaran yang diinginkan. Oleh karena itu, seharusnya siswa lebih aktif dalam 
proses pembelajaran (Jayawardana, 2017). Selama proses pembelajaran, aktivitas siswa merupakan hal yang perlu diperhatikan karena pada prinsipnya belajar adalah berbuat (learning by doing). Berbuat untuk mengubah tingkah laku artinya melakukan sesuatu kegiatan atau aktivitas. Tidak ada belajar kalau tidak ada aktivitas karena tanpa aktivitas proses pembelajaran tidak mungkin berlangsung dengan baik. Itulah sebabnya aktivitas siswa merupakan prinsip atau asas yang sangat penting dalam proses pembelajaran (Syairani \& Rosita, 2015).

Biologi merupakan salah satu mata pelajaran yang mengharuskan siswa agar terlibat aktif dalam pembelajaran. Karakteristik biologi memiliki cakupan materi yang sangat luas karena berkaitan erat dengan kehidupan sehari-hari terkait hal tersebut, menurut Solikhatun (2015), sebagian besar siswa menganggap pelajaran biologi sebagai pelajaran hafalan, sehingga siswa cenderung mencatat dan mendengarkan guru selama proses pembelajaran di kelas. Proses pembelajaran yang demikian merupakan proses pembelajaran yang berpusat pada guru. Sehubungan dengan hal tersebut, menurut Jayawardana (2017), pembelajaran yang berpusat pada guru cenderung membuat siswa pasif dan akibatnya siswa mudah bosan sehingga kemungkinan besar tidak dapat mengikuti pelajaran dengan baik.

Kualitas hasil belajar siswa salah satunya ditentukan oleh proses pembelajaran (Jayawardana, 2017). Proses pembelajaran yang kurang menyenangkan dapat disebabkan oleh faktor penerapan model pembelajaran konvensional yang mendominasi dan menitikberatkan pada guru sebagai sumber informasi. Selain itu, proses pembelajaran cenderung diarahkan semata-mata untuk menyelesaikan materi akibatnya aktivitas siswa menjadi rendah dan hasil belajar siswa kurang optimal (Syairani \& Rosita, 2015). Dominansi pendekatan pembelajaran teacher center dapat menyebabkan aktivitas lisan (oral activity) siswa rendah yang meliputi bertanya, menjawab pertanyaan, dan menyampaikan pendapat. Pembelajaran biologi berpegang pada prinsip learning by doing, menekankan pada aktivitas siswa sehingga siswa perlu dihadapkan pada suatu permasalahan untuk memecahkan masalah dan menemukan solusinya.

Fakta yang ditemukan di lapangan yaitu guru masih menggunakan pendekatan pembelajaran yang berpusat pada guru. Guru hanya menyampaikan garis besar materi pembelajaran, menuliskan point-point materi pembelajaran, membuat peta konsep dan meminta siswa untuk membuat catatan berupa rangkuman yang dikumpulkan pada akhir pembelajaran. Siswa cenderung mendengarkan penjelasan guru dan mengikuti instruksi guru untuk membuat rangkuman. Kondisi itu menyebabkan siswa cenderung kurang aktif selama proses pembelajaran, siswa kurang mendapatkan kesempatan untuk menyampaikan pendapat, bertanya dan presentasi. Selain itu, ketika guru menyampaikan materi, masih ada beberapa siswa yang tidak memperhatikan penjelasan guru, dan ada yang berbicara dengan teman sebelahnya yang tidak terkait dengan materi pembelajaran. Akibatnya ketika guru bertanya kepada siswa hanya sedikit siswa yang dapat menjawab pertanyaan. Guru juga kurang memotivasi siswa agar berani mengajukan pertanyaan yang terkait dengan materi pembelajaran. Hal ini mengindikasikan partisipasi siswa terutama aktivitas lisan (oral activity) selama pembelajaran masih rendah. Menurut Sardiman (2014), oral activity merupakan kegiatan yang dilakukan untuk menyatakan, merumuskan, bertanya, memberi saran, mengeluarkan pendapat, mengadakan wawancara, diskusi dan interupsi.

Berdasarkan wawancara kepada salah satu guru mata pelajaran biologi diperoleh informasi salah satu materi Biologi kelas XI MIPA pada semester genap tahun ajaran 2018/2019 yang membuat siswa kesulitan untuk menguasai materi adalah materi sistem ekskresi. Hal ini karena pada materi sistem ekskresi memuat banyak proses yang terjadi dan melibatkan banyak organ-organ yang berperan pada materi sistem ekskresi. Selain itu, berdasarkan hasil belajar yang diperoleh siswa kelas XI MIPA tahun ajaran 2018/2019 pada materi sistem ekskresi memiliki nilai ratarata yang paling rendah dibandingkan materi mata pelajaran Biologi yang lain. Pembelajaran Biologi pada materi sistem ekskresi juga belum memunculkan permasalahan yang berkaitan dengan kehidupan sehari-hari. Kondisi yang 
demikian perlu adanya penerapan model pembelajaran yang dapat memfasilitasi siswa untuk memecahkan permasalahan yang berkaitan dengan kehidupan nyata. Salah satunya dengan penerapan model pembelajaran SSCS (Search, Solve, Create and Share) yang berorientasi pada pemecahan masalah.

Hasil belajar kognitif adalah hasil belajar yang berhubungan dengan keguatan mental atau otak (Sudjana, 2016). Hasil belajar kognitif dan oral activity siswa juga akan baik dan meningkat jika pembelajaran dapat berlangsung secara efektif dan ditunjang dengan penggunaan model pembelajaran yang sesuai dengan materi dan tujuan pembelajaran. Model pembelajaran yang dapat digunakan adalah model SSCS (Search, Solve, Create and Share). Model pembelajaran SSCS (Search, Solve, Create and Share) merupakan model pembelajaran yang mengarahkan siswa untuk dapat menguraikan, menghubungkan dan menganalisis masalah hingga sampai tahap penyelesaian masalah sehingga menuntut siswa untuk aktif berdiskusi dalam kelompokkelompok kecil selama pembelajaran. Penelitian terdahulu yang pernah dilakukan oleh Astuti dkk (2019), mengungkapkan bahwa penerapan model pembelajaran berbasis masalah dapat meningkatkan hasil belajar ranah kognitif siswa pada pembelajaran biologi.

Berdasarkan uraian di atas, perlu adanya penelitian studi literatur untuk membahas pembelajaran biologi yang melibatkan aktivitas siswa di dalam kelas terutama aktivitas lisan (oral activity). Hal ini karena masih terdapat pembelajaran yang memusatkan segala kegiatan pada guru. Lebih lanjut, kajian mengenai model pembelajaraan SSCS (Search, Solve, Create and Share) akan dikaitkan dengan perolehan hasil belajar siswa pada materi Biologi sistem ekskresi. Mengingat pentingnya kajian di atas maka penulis menggagas suatu studi literatur yang berjudul Peningkatan Oral Activity dan Hasil Belajar Kognitif melalui Penerapan Model Pembelajaran SSCS (Search, Solve, Create and Share) Materi Sistem Ekskresi pada Manusia.

\section{Metode Penelitian}

\section{Jenis Penelitian}

Penelitian ini menggunakan jenis penelitian studi literatur. Literatur review adalah penelitian yang dilakukan dengan membandingkan berbagai penelitian terdahulu kemudian dikaitkan dengan suatu topik penelitian yang dijadikan sebagai fokus review (Efron \& Ravid, 2019). Desain penelitian yang digunakan yaitu narrative review. Narrative review atau sering disebut dengan traditional literature review merupakan jenis literatur review dengan analisis dan sintesis secara menyeluruh untuk membangun sebuah teori dan konteks terhadap suatu fokus penelitian (Stratton, 2019).

\section{Prosedur Penelitian}

Kriteria artikel ilmiah yang digunakan sebagai data berupa artikel ilmiah yang bersumber dari jurnal, prosiding,dan repository dengan kemutakhiran 10 tahun terakhir yaitu dari tahun 2011-2020. Data artikel ilmiah yang digunakan minimal 30 artikel. Artikel ilmiah merupakan artikel yang dapat diakses secara terbuka oleh publik. Langkah-langkah yang dilakukan dalam rangka pencarian artikel sebagai data penelitian literatur sebagai berikut:

(1) Mengunjungi ke beberapa web berikut ini https://eric.ed.gov, https://www.doaj.org, http://garuda.ristekbrin.go.id, https://scholar.google.co.id.

(2)Memasukkan kata kunci pencarian model pembelajaran Search, Solve, Create and Share (SSCS) oral activity dan hasil belajar kognitif siswa pada materi sistem ekskresi manusia pada kotak pencarian masingmasing web. Berdasarkan hasil penelusuran diperoleh jumlah artikel sesuai kata kunci melalui web https://eric.ed.gov sebanyak 3 artikel, web https://www.doaj.org sebanyak 17 artikel, web http://garuda.ristekbrin.go.id sebanyak 78 artikel, dan web https://scholar.google.co.id sebanyak 152 artikel. Secara keseluruhan jumlah artikel ilmiah berdasarkan penelusuran kata kunci sebanyak 250 artikel.

(3)Tahap selanjutnya dilakukan filterisasi artikel ilmiah dengan cara mengeliminasi artikel ilmiah dengan gagasan topik yang sama jika ditemukan pada setiap sumber untuk meminimalkan kemungkinan gagasan topik penelitian yang rangkap, artikel ilmiah juga diseleksi berdasarkan tahun yaitu dari 
tahun 2011-2020. Data artikel ilmiah yang diperoleh pada tahap ini sebanyak 64 artikel ilmiah.

\section{Validasi/Review Kualitas Literatur}

Artikel ilmiah yang diperoleh berdasarkan kata kunci model pembelajaran Search, Solve, Create and Share (SSCS) oral activity dan hasil belajar kognitif siswa pada materi sistem ekskresi manusia sebanyak 64 artikel. Selanjutnya dilakukan review kualitas artikel ilmiah yang relevan dengan topik penelitian dengan cara membaca keseluruhan isi artikel ilmiah yang bertujuan melihat kesesuaian dengan topik penelitian diperoleh jumlah artikel sebanyak 35 artikel ilmiah yang relevan dengan topik penelitian.

Review kualitas literatur dilakukan dengan filterisasi artikel ilmiah yang akan digunakan untuk penelitian. Proses review kualitas literatur ini dilakukan dengan mempertimbangkan beberapa hal. Pertimbangan yang dijadikan sebagai dasar review kualitas literatur yaitu sumber pencarian artikel ilmiah yang terpercaya meliputi: 1) artikel ilmiah dapat diakses secara terbuka dan tidak berbayar melalui sumber web yang terpercaya; 2) kualitas metodologi penelitian yang digunakan pada artikel ilmiah termasuk dalam penelitian tindakan kelas dan quasi experiment; 3) kualitas penyajian data dan pembahasan; 4) kecukupan data yang relevan digunakan dalam analisis literatur; dan 5) referensi yang mutakhir tahun 2011-2020.

Data yang disajikan dalam penelitian diawali dengan pencarian artikel ilmiah yang relevan dengan Peningkatan Oral Activity dan Hasil Belajar Kognitif Siswa Melalui Penerapan Model Pembelajaran SSCS (Search, Solve, Create and Share) pada Materi Sistem Ekskresi Manusia. Daftar artikel ilmiah yang digunakan pada penelitian ini disajikan dalam bentuk tabel dengan format nomor, judul artikel, tahun peneliti, nama jurnal, dan link website.

Teknik analisis literatur yang dilakukan pada penelitian ini adalah deskriptif. Pendekatan deskriptif dilakukan dengan cara mendeskripsikan temuan hasil analisis pada artikel ilmiah yang digunakan sebagai data penelitian kemudian direpresentasikan dalam bentuk kalimat. Hal ini bertujuan agar dapat memberikan penjelasan lebih luas dan mendalam dari hasil analisis sehingga lebih mudah dipahami (Habsy, 2017).

\section{Hasil Penelitian dan Pembahasan}

\section{Hasil Penelitian}

Data artikel ilmiah yang digunakan dalam penelitian yang sudah divalidasi kemudian dikelompokkan berdasarkan pencarian koding definisi yang sesuai dengan gagasan penelitian. Pengelompokan artikel ilmiah penelitian ini disajikan dalam bentuk tabel sebagai berikut:

\begin{tabular}{|c|c|c|c|c|c|}
\hline $\begin{array}{c}\text { Model } \\
\text { Pembela } \\
\text { jaran }\end{array}$ & $\begin{array}{l}\text { Hasil } \\
\text { Belaja } \\
\text { r } \\
\text { Kognit } \\
\text { if }\end{array}$ & $\begin{array}{c}\text { Oral } \\
\text { activ } \\
\text { ity }\end{array}$ & $\begin{array}{c}\text { Materi } \\
\text { Sistem } \\
\text { Ekskre } \\
\text { si }\end{array}$ & $\begin{array}{c}\text { Vari } \\
\text { abel } \\
\text { Lai } \\
\text { n }\end{array}$ & Total \\
\hline SSCS & 14 & 4 & 2 & 15 & 35 \\
\hline
\end{tabular}

Artikel ilmiah yang digunakan pada penelitian ini awalnya diperoleh 64 kemudian setelah dilakukan filterisasi diperoleh 35 artikel ilmiah yang relevan. Secara rinci perolehan 35 artikel ilmiah yang digunakan sebagai data penelitian dan relevan dengan judul penelitian yaitu terdapat 14 artikel model pembelajaran SSCS terkait hasil belajar kognitif, 4 artikel model pembelajaran SSCS terkait oral activity, 2 artikel model pembelajaran SSCS terkait materi sistem ekskresi dan 15 artikel model pembelajaran SSCS terkait variabel lain.

\section{Pembahasan}

Data artikel ilmiah yang relevan dengan gagasan judul penelitian yang diperoleh kemudian dilakukan review yang penyajiannya dalam bentuk oral activity. Oral activity siswa merupakan salah satu aktivitas belajar siswa yang meliputi menyatakan, merumuskan, bertanya, memberi saran, mengeluarkan pendapat, mengadakan wawancara, diskusi, dan interupsi (Sardiman, 2014). Perlunya meningkatkan oral activity siswa dalam pembelajaran biologi bertujuan agar tercipta pembelajaran yang aktif. Hal ini karena pembelajaran biologi berkaitan erat dengan kehidupan sehari-hari sehingga siswa harus berperan aktif dalam pembelajaran dan mempunyai minat bertanya yang tinggi. 


\section{Penerapan model pembelajaran Search, Solve, Create and Share (SSCS) untuk meningkatkan oral activity.}

Model pembelajaran SSCS merupakan model pembelajaran yang melibatkan siswa agar berpartisipasi secara aktif untuk menyelesaikan permasalahan yang berkaitan dengan kehidupan nyata sehingga dapat diterapkan pada pembelajaran biologi. Sintak pada model pembelajaran SSCS yaitu search siswa mencari tahu permasalahan kemudian menuliskannya, solve siswa merencanakan penyelesaian masalah, create siswa membuat penyelesaian masalah, share siswa untuk mempresentasikan hasil penyelesaian masalah.

Tabel 2. Hasil Review Artikel Ilmiah yang Relevan

\begin{tabular}{|c|c|c|}
\hline No & Judul Artikel & Hasil Review \\
\hline 1. & $\begin{array}{lr}\text { Pengaruh } & \begin{array}{r}\text { Model } \\
\text { Search, } \\
\text { Create, }\end{array} \\
& \text { Solve, } \\
\text { (SSCS) } & \text { Terhadap } \\
\text { Aktivitas } & \text { dan } \\
\text { Hasil } & \text { Belajar } \\
\text { Biologi } & \text { Siswa } \\
\text { Kelas X } & \text { SMA } \\
\text { Negeri } & 1 \\
\text { Tinambung } & \\
\text { Kabupaten } & \\
\text { Polewali Mandar }\end{array}$ & $\begin{array}{l}\text { Berdasarkan hasil penelitian } \\
\text { model pembelajaran SSCS } \\
\text { berpengaruh terhadap hasil } \\
\text { belajar dan aktivitas siswa. } \\
\text { Hal ini dibuktikan dengan } \\
\text { perbedaan yang signifikan } N \text { - } \\
\text { Gain terhadap aktivitas dan } \\
\text { hasil belajar biologi siswa } \\
\text { ranah kognitif pada kelas } \\
\text { yang menggunakan model } \\
\text { pembelajaran SSCS }\end{array}$ \\
\hline 2. & $\begin{array}{l}\text { Penerapan Model } \\
\text { Search, Solve, } \\
\text { Create, Share } \\
\text { (SSCS) pada } \\
\text { Materi Perubahan } \\
\text { Lingkungan } \\
\text { Untuk } \\
\text { Meningkatkan } \\
\text { Hasil Belajar dan } \\
\text { Aktivitas Siswa Di } \\
\text { SMA }\end{array}$ & $\begin{array}{l}\text { Berdasarkan hasil penelitian } \\
\text { diketahui } \\
\text { pembelajaran } \\
\text { berpengaruh } \\
\text { meningkatkan hasil belajar } \\
\text { dan aktivitas siswa. Model } \\
\text { pembelajaran SSCS dapat } \\
\text { meningkatkan hasil belajar } \\
\text { kognitif dan oral activity } \\
\text { siswa. Hal ini dibuktkikan } \\
\text { perbedaan yang signifikan } \\
\text { hasil belajar kognitif dan orl } \\
\text { activity siswa. Sintak model } \\
\text { pembelajaran } \\
\text { mendukung oral activity } \\
\text { siswa pada tahapan solve dan } \\
\text { share. }\end{array}$ \\
\hline 3. & $\begin{array}{l}\text { Pengaruh } \\
\text { Penerapan Model } \\
\text { Pembelajaran } \\
\text { Search, Solve, } \\
\text { Create and Share } \\
\text { Terhadap } \\
\text { Kemampuan } \\
\text { Berpikir Tingkat } \\
\text { Tinggi Siswa } \\
\text { Kelas XI SMA }\end{array}$ & $\begin{array}{l}\text { Berdasarkan hasil penelitian } \\
\text { diketahui bahwa model } \\
\text { pembelajaran } \\
\text { berpengaruh } \\
\text { kemampuan berpikir tingkat } \\
\text { tinggi siswa pada materi } \\
\text { sistem ekskresi. Hal ini } \\
\text { dibuktikan dengan rata-rata }\end{array}$ \\
\hline
\end{tabular}

\begin{tabular}{llll}
\hline Unggul Negeri 4 & nilai & $N$-Gain pada kelas \\
Palembang pada & eksperimen lebih tinggi \\
Pembelajaran & daripada kelas kontrol. \\
Materi $\quad$ Sistem & & \\
Ekskresi & & \\
\hline
\end{tabular}

Hal ini diperkuat oleh penelitian yang pernah dilakukan oleh Irwan (2011), model pembelajaran Search, Solve, Create and Share (SSCS) meliputi empat fase, yaitu fase Search merupakan fase ketika siswa mengidentifikasi masalah, kedua fase Solve merupakan fase ketika siswa menyusun perencanaan berkaitan dengan penyelesaian masalah, ketiga fase Create merupakan fase ketika siswa membuat penyelesaian masalah, dan keempat fase Share merupakan fase ketika siswa mengkomunikasikan hasil penyelesaian masalah.

Penelitian yang pernah dilakukan oleh Fatiya, Partaya, \& Dewi (2019), menyatakan bahwa model pembelajaran SSCS berpengaruh secara signifikan untuk meningkatkan aktivitas siswa termasuk oral activity siswa. Model pembelajaran SSCS dapat membantu untuk meningkatkan keterlibatan siswa agar aktif dalam pembelajaran untuk memecahkan masalah. Temuan yang diperoleh pada penelitian ini yaitu model pembelajaran SSCS efektif untuk meningkatkan oral activity siswa yang dapat diamati pada tahap solve dan share. Tahapan solve, siswa harus aktif berdiskusi dengan temannya dalam memecahkan permasalahan yang terkait dengan materi pembelajaran. Tahap share, siswa mengkomunikasikan hasil penyelesaian masalah kepada teman-temannya. Berdasarkan penelitian tersebut penerapan model pembelajaran SSCS dapat meningkatkan oral activity siswa pada sintak solve dan share. Tahap solve, indikator yang mendukung oral activity siswa yaitu berdiskusi dengan teman satu kelompoknya dalam rangka menyusun dan melaksanakan perencanaan untuk menyelesaikan masalah. Tahap share, ketika siswa mengkomunikasikan hasil penyelesaian masalah dapat memunculkan indikator yang mendukung oral activity siswa yaitu diskusi, menyatakan pendapat, bertanya, memberi saran dan menanggapi presentasi hasil penyelesaian masalah antar kelompok. Tahapan search dan create tidak memperlihatkan indikator oral activity siswa. Aktivitas yang teramati pada tahap search yaitu visual activity dan listening activity sedangkan pada tahap create yaitu 
writting activity. Seharusnya penerapan model pembelajaran SSCS dapat menumbuhkan oral activity pada setiap sintak pembelajaran. Hal ini karena model pembelajaran SSCS melibatkan siswa agar berdiskusi secara aktif untuk menyelesaikan masalah sehingga semestinya sintak model pembelajaran search dan create dapat memperlihatkan oral activity siswa.

\section{Penerapan model pembelajaran Search, Solve, Create and Share (SSCS) untuk meningkatkan hasil belajar kognitif siswa}

Partisipasi siswa yang aktif dalam pembelajaran dapat membantu siswa memperoleh pembelajaran bermakna sehingga pencapaian hasil belajar kognitif siswa baik. Menurut Sudjana (2016), hasil belajar kognitif merupakan kemampuan dalam aspek pengetahuan yang dimiliki oleh siswa setelah menerima pengalaman belajar. Hasil belajar kognitif siswa dapat meningkat apabila siswa mempunyai peran aktif selama proses pembelajaran. Penerapan model pembelajaran SSCS dapat mendukung siswa menjadi lebih aktif terlibat selama proses pembelajaran sehingga siswa dapat menguasai materi dan memperoleh hasil belajar kognitif yang tinggi. Desain model pembelajaran SSCS untuk memecahkan masalah mendukung siswa aktif dalam belajar. Siswa yang aktif dalam pembelajaran akan memperoleh pengalaman belajar secara langsung sehingga hasil belajar kognitif siswa tinggi.

Berdasarkan hasil review, penelitian yang dilakukaan oleh Amalia \& Budianto (2019), siswa yang sudah terbiasa dibelajarkan dengan menggunakan model pembelajaran SSCS akan berpengaruh secara signifikan terhadap peningkatan hasil belajar kognitif siswa. Hal ini karena pada tahapan model pembelajaran SSCS menuntut siswa agar aktif selama pembelajaran dan terbiasa melakukan proses befikir. Sejalan dengan penelitian Djumadi \& Santoso (2014), sintak model pembelajaran SSCS melatih siswa untuk belajar mandiri dan terlibat aktif dalam pembelajaran sehingga rata-rata hasil belajar kognitif yang diperoleh siswa tinggi. Temuan yang diperoleh model pembelajaran SSCS berpengaruh terhadap hasil belajar kognitif siswa. Hal ini sesuai dengan penelitian yang pernah dilakukan oleh Maulana, Anom, \&
Sofia (2014), penerapan model pembelajaran SSCS berpengaruh terhadap hasil belajar kognitif siswa. Temuan yang diperoleh yaitu hasil belajar siswa lebih tinggi dengan menggunakan model pembelajaran SSCS. Proses penyelesaian masalah memicu siswa agar aktif dalam belajar sehingga mempermudah siswa menguasai materi lebih baik. Berkaitan dengan hal tersebut, sesuai dengan penelitian yang pernah dilakukan oleh Utami (2011), membuktikan bahwa model pembelajaran SSCS berpengaruh terhadap peningkatan prestasi belajar siswa. Hal ini karena kemampuan berpikir, penyelesaian masalah dan pengetahuan yang dimiliki siswa lebih berkembang sehingga prestasi belajar yang diperoleh siswa tinggi.

\section{Penerapan model pembelajaran Search, Solve, Create and Share (SSCS) pada materi sistem ekskresi}

Materi sistem ekskresi merupakan salah satu materi yang berkaitan dengan kehidupan sehari-hari. Karakteristik materi sistem ekskresi bersifat konkret, prosesnya tidak dapat diindera dan saling berhubungan. Karakteristik materi sistem ekskresi yang demikian dapat diterapkan menggunakan model pembelajaran SSCS. Hal ini karena model pembelajaran SSCS merupakan model pembelajaran yang berorientasi pada pemecahan masalah yang berkaitan dengan kehidupan sehari-hari. Selain itu, model pembelajaran SSCS mempunyai kelebihan untuk meningkatkan kemampuan berpikir dan interaksi siswa saat kegiatan pembelajaran berlangsung. Siswa dapat merasakan pembelajaran yang bermakna. Desain model pembelajaran SSCS tersebut cocok untuk diterapkan pada pembelajaran biologi materi sistem ekskresi. Berkaitan dengan hal tersebut, berdasarkan hasil review sesuai dengan penelitian yang pernah dilakukan oleh Fatiyah, Susanti, \& Santoso (2014), materi sistem ekskresi merupakan materi yang berkaitan dengan kehidupan nyata, memuat proses fisiologis yang saling berhubungan dan tidak dapat diindera. Siswa perlu dibelajarkan menggunakan model pembelajaran yang memberikan kesempatan untuk berperan aktif dan mengembangkan kemampuan berpikir. Penerapan model pembelajaran SSCS dapat berpengaruh meningkatkan kemampuan berpikir tingkat tinggi siswa pada materi sistem 
ekskresi. Kemampuan berpikir tingkat tinggi dalam ranah kognitif meliputi menganalisis (C4), mengevaluasi (C5) dan mencipta (C6). Pernyataan ini diperkuat oleh penelitian Fatiyah, Susanti, \& Santoso (2014), siswa yang memiliki kemampuan berpikir tingkat tinggi dapat membantu siswa menjawab soal-soal menganalisis (C4), mengevaluasi (C5) dan mencipta (C6). Apabila dikaitkan dengan materi sistem ekskresi dalam hal ini penerapan model pembelajaran SSCS dapat membantu siswa dalam menjawab pertanyaan sampai kompetensi dasar menganalisis (C4). Kompetensi dasar menganalisis pada materi sistem ekskresi yaitu siswa dapat membedakan, mengurutkan dan menghubungkan antara struktur jaringan penyusun organ pada sistem ekskresi yang kemudian dikaitkan dengan proses fisiologis dan gangguan fungsi yang dapat terjadi pada sistem ekskresi manusia.

\section{Kesimpulan}

Kesimpulan yang diperoleh berdasarkan penelitian ini sebagai berikut: (1) Berdasarkan studi literatur model pembelajaran SSCS dapat meningkatkan oral activity siswa. Hal ini dapat diketahui dari analisis data pada artikel ilmiah yang relevan menunjukkan adanya pengaruh yang signifikan peningkatan oral activity siswa yang terlihat pada sintak model pembelajaran SSCS yaitu solve dan share ketika siswa berdiskusi dalam kelompoknya dan antar kelompok lain. Siswa mempunyai kesempatan untuk bertanya, menjawab pertanyaan dan menyampaikan pendapatnya. (2) Berdasarkan studi literatur model pembelajaran SSCS dapat meningkatkan hasil belajar kognitif siswa. Hal ini diketahui dari analisis data artikel ilmiah yang relevan menunjukkan ada pengaruh yang signifikan terhadap peningkatan hasil belajar ranah kognitif siswa. Hal tersebut karena model pembelajaran SSCS berorientasi pada pemecahan masalah yang mendukung siswa untuk mengembangkan kemampuan berpikir dan memperoleh pembelajaran bermakna sehingga hasil belajar kognitif siswa meningkat. (3) Berdasarkan studi literatur model pembelajaran SSCS dapat diterapkan pada materi sistem ekskresi. Hal ini karena materi sistem ekskresi merupakan materi yang berkaitan dengan kehidupan sehari-hari. Penerapan model pembelajaran SSCS merupakan model pembelajaran yang berorientasi pada pemecahan masalah kehidupan nyata sehingga cocok diterapkan pada materi sistem ekskresi.

\section{Daftar Pustaka}

Amalia \& Budianto. 2019. "Pengaruh Penggunaan Model Search, Solve, Create and Share Terhadap Hasil Belajar Biologi Materi Virus Siswa Kelas X SMA AL-Masdar Batang Kuis". Biology Education Science Technology, 2(01) 60-68.

Astuti dkk. 2019. "Pembelajaran Berbasis Masalah Biologi Pada Aspek Kognitif: Sebuah MetaAnalisis". JPBIO (Jurnal Pendidikan Biologi), 4(2), 67-74.

Djumadi, \& Santoso, E. B. 2014. "Pengaruh Model Pembelajaran Search, Solve, Create, and Share dan Predict Observe Explain Terhadap Hasil Belajar Biologi Siswa Kelas VIII SMPN 1 Gondangrejo Karanganyar Tahun Ajaran 2013/2014". Jurnal Varia Pendidikan, 26(1), 11-20.

Efron \& Ravid. 2019. Writing The Literature Review: Practical Guide. New York: The Guilford Press.

Fatiya, Partaya, \& Dewi. 2019. "Penerapan Model Search, Solve, Create, Share (SSCS) Pada Materi Perubahan Lingkungan Untuk Meningkatkan Hasil Belajar dan Aktivitas Siswa di SMA". Bioma, 8, 291-303.

Fatiyah, Susanti, \& Santoso. 2014. "Pengaruh Penerapan Model Pembelajaran Search, Solve, Create and Share terhadap Kemampuan Berpikir Tingkat Tinggi Peserta Didik Kelas XI SMA Unggul Negeri 4 Palembang Pada Pembelajaran Materi Sistem Ekskresi". Prosiding Seminar Nasional Pendidikan IP. 504-513.

Habsy, B. A. 2017. "Seni Memahami Penelitian Kuliatatif Dalam Bimbingan Dan Konseling: Studi Literatur". Jurnal Konseling Andi Matappa, 1, 90-100..

Irwan. 2011. "Pengaruh Pendekatan Problem Posing Model Search, Solve, Create, Share (SSCS) dalam Upaya Meningkatkan Kemampuan Penalaran Matematis Mahasiswa Matematika". Jurnal Penelitian Pendidikan, 12(1).

Jayawardana, H. B. 2017. "Paradigma Pembelajaran Biologi di Era Digital". Jurnal Bioedukatika, 5(1), 12-17.

Maulana, A., Anom, K., \& Sofia. 2014. "Penerapan Model Pembelajaran Search Solve Create and Share (SSCS) Untuk Meningkatkan Hasil Belajar Siswa Di Kelas XI IPA SMA". Jurnal Pendidikan Kimia, 1 No. 1, 9-17.

Sardiman. A. M. 2014. Interaksi dan Motivasi Belajar Mengajar. Jakarta: Rajagrafindo. 
Solikhatun, I., Santosa, S., \& Mariadi. 2015. "Pengaruh Penerapan Reality Based Learning Terhadap Hasil Belajar Biologi Siswa Kelas X SMA Negeri 5 Surakarta Tahun Pelajaran 2012/2013". Jurnal Pendidikan Biologi, 7(3), , 49-60.

Stratton, S. J. 2019. "Literature Reviews : Methods and Applications". Prehospita and Disaster Medicine, 34(4), 5-7.

Sudjana, N. 2016. Penilaian Hasil Proses Belajar Mengajar. Bandung: PT Remaja Rosdakarya.
Syairani, \& Rosita, T. 2015. "Efektivitas Model Pembelajaran Berbasis Masalah (Problem Based Learning) Terhadap Hasil Belajar Siswa Pada Sub Materi Ekosistem Di Kelas X SMA Negeri 1 Percut Sei Tuan T. P. 2014/2015". Jurnal Pelita Pendidikan, 3(4), 216-227.

Utami, R.P. 2011. "Pengaruh Model Pembelajaran Search Solve Create And Share (SSCS) dan Problem Based Instruction (PBI) Terhadap Prestasi Belajar dan Kreativitas Siswa. BIOEDUKASI, 4(2), 57-71. 